\title{
屎尿中の蛔虫卵殺隇剤の研究
}

\author{
石井信太郎・三戶部亀夫 \\ 橫浜医科大学

\section{STUDIES OF THE CHEMICALSA GAINST ASCARIS-EGGS IN THE NIGHT-SOIL}

\author{
NOBUTARo ISHII and KAMEO MITOBE \\ Yokohama University, School of Medicine
}

\section{1. 緒言}

我国に於ける蛔虫の感染は屎尿を肥料をする点に最も負うところがあると考えられる ので西るが，農村に於ける蚵虫の感染が都市に於けるよりも，上迎わ的いることは， 畑地等に屎尿を撤布方るがために, 土壤は蜔虫卵に污染せられ，風塺を共に飛散た蜔虫 卵が感染の源となることは理の当然で西り，野茶類に附着した蜔虫卵が漬物等として感 染の機会を作るということも農村に於けるばかりでなく都市に於ても重要な感染源であ ると認めねばならをい。

化学肥料疼日本全国に普及することは将来の課題として重要なことで西るが，莒来屎 尿を肥料とする日本農業は然く簡学には化学肥料に切椇えることをさせないであるう。 それで屎尿を以てする㖘作物はまだまだ永続すると考元るべぎ西るから，蜔虫寄生者 の駆虫を行う一方に蜔虫の感染源も防除することは極めて肝要を事柄と考えられる.

さて屎尿中に於ける蜔出卵をどの寄生虫卵を殺滅する方途は徉来改究されてはいる が，却々に有效な方法で簡易に実施し得べきものはないようで西る。

改良便所は最も実施されているもので西るが，まだ日本全国に桩大されていないのは 費用の点に難点があると同時に農村では長特日屎尿を放置するという点で好まれないた めに改良便所有効に使用することにならないなどの不都合が多々亦るのでする。

結局は費用が低廉で西り，虫卵殺滅が短時間になされ，手間が多くかからないという 方法でなければ，実用上好適で西るとはいえないので西る。

上述の条件に適合すべき方法として先づ考えられることは，薬戍を用うることでする

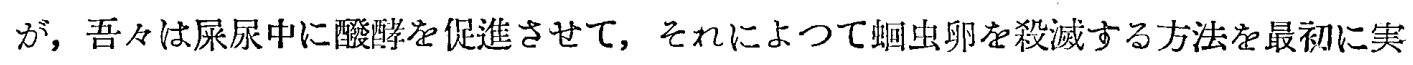
験的に試みたので㐫るが，好適なものを発見出来なからたのである.

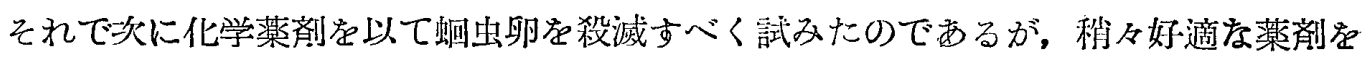
見出したのである。

そして其後引続き諸種の化学薬品友以て実験を行つているので西るが, 未だそれ以上 の薬品を発見するに至つていないのは遺憾でするが，一応上記の化学楽品について報告 することとする。 


\section{2. 実 験 方 法}

化学薬品を康尿中に混和し，蚵虫卵（蜔虫卵が抵抗性が強度なので蜔虫卵を目標とし て実験を行つたので西るが他種寄生虫卵は当然対称となるのである）を殺滅する可能性 を検討したので西る.

実験に際しては自然状態に近い方法を用うべく実験室內又は空外に於て行つたので西 るが，小型屎尿溜として㗂子円筒を用い，之に蜔虫卵多数を合む尿尿を容れた。

蜔虫卿のみを集めて尿尿のないものに薬品を作用させるのは，実際の場合と差異が西 ることは明かで西るのでこの方法は採らなかつた。即ち蝶品は屎尿に混和せられて多少 なりとも化学変化を起すと考えられ，それで同且つ殺卵作用が西ることが必要で西るの で，斯様な実験は屎尿そのまま蛋用いた方が成續に誤まりがをいので西る.

それで吾々は屎尿をそのまま用いて実験したので西るが，笑験容器に尿尿を容れるに

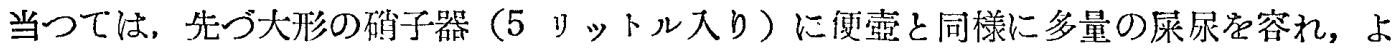

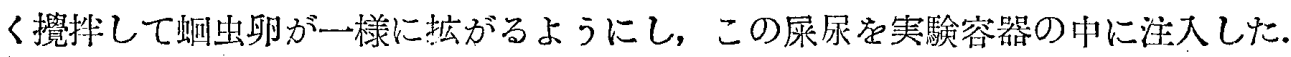

実験容器には $300 \mathrm{cc}$ の屎尿它容れここれに種々のパーセントに試験薬品を投入混和 したのである。

薬品の投入量：薬品の投入に際しては多量で西れば 殺卯效果宗すことは容易で两 ることは勿論であるから，多量の薬品を用うることは考えられるところで西るが，やた らに多量の薬品を尿尿中に混大することは害用上に難点が西るので画る.

即ち経済的には高価となり実施に当つては感心されないので西る，少量の薬品で低廉 で效果を発揮するものが望ましいので西る，又この屎尿究肥料として朋いる場合に薬品

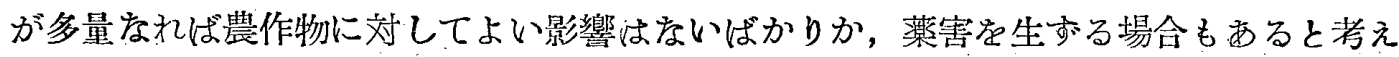
ねばならない。

更に薬品の使用混入に際して，多量で西れば運般，操作等の手間が增加し，実用する には多忙な農耕者の労力增すことに崖り，徒つて実用価值は減ぜられるので西る。

以上の意味からして吾々は次の如き投大量を定めたので西る.

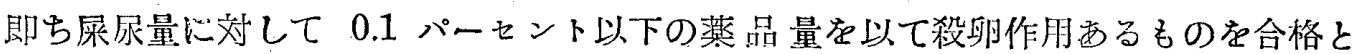
したので西る.

そを䒠例として述べれば，農家の痞尿溜は関東地方に於ては 1 不，2石入れが多いよ うで两つて，1石は約 20つリトッルとすれば之に 0.1 パーセントの割に萖品存混ぜるに は200グラムの薬品を用うればよいので西る。この量をれ称入混和の操作は大しせ学 力农要せす、，運搬も問題とする程でもないので西る。

若し 1.0 パーセントの割合に薬品を投入するとすれば, 2 キログラムの薬品を要する ことになるのである。

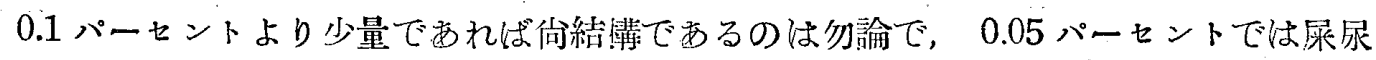
量 1 石に刘して 100 グラムの薬品炎投入混和方ればよいので西る.

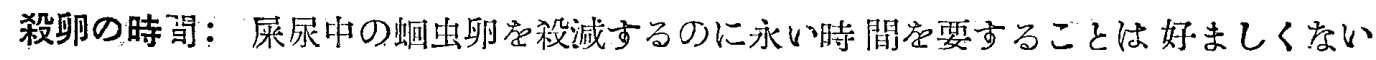

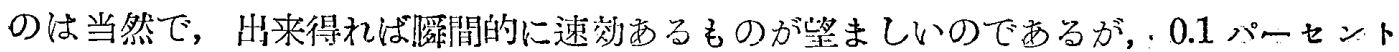


以下の少量では恐らく西り得ないのでする.

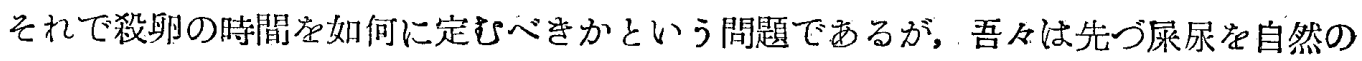
状態に放置した場合に夏季に於ては慼熟のために蜔虫卵が死隇するのに大略 1 カ月要 することが知られているので。これよりも短特間で殺卵せねば意䡤がないということに なるのである。

殺卵時間の短かい程よいので西るが，1 1 月の 3 分の 1 Łして 10 日以內に殺卵を完

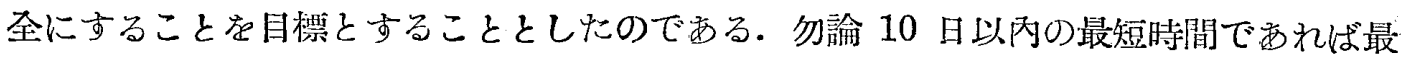

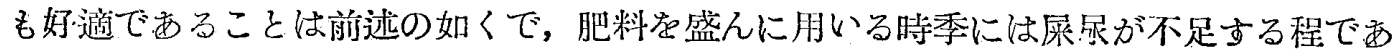
つて，1日放置することさえ却々むすかしい程で西るから，実際問䞨としては困難な問 題で西る.

肥料としての価值：尿㲾中に薬品を投入混和し蛔出卵在殺隇して後に，この屝尿を 肥料として農作物に施す場合に屎尿中に混科せられた薬品が農作物に有害で西つてはな

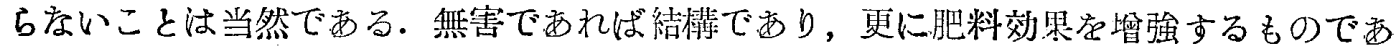
れば然ましいものである。

その意味で吾々は殺卵作用存有する薬品を尿尿中に混和して後に実験的に植物に対す る害作朋を検したのである。植物としてはサラダ荣を硝子器に土を盛つて植え，これに 該屎尿を施してサラダ荣に対する害作用を検したのであるが，サラダ荣の発育に刘して のみならず，棐に対して害作用が西るかどうかをも検したので西る。この場合には対照 として水のみ在施したサラダ荣在以て此校したので西る。

サラダ荣は植物として比較的弱いもので雨つて，その葉は薬品によつて容易に影響存 受けるもので㐫るので,このサラダ荣名以てした実験に合格すれば他種農作物に対して の害作用は無いとみて差支えないと考えられるので西る。

試験の時季：薬品の作用は溫度によつて左右されるものであることは一般に認めら れるところで西るので，吾↔の実験は春秋の候に主として行つたのである。

即ち夏季の高溫時には薬品の作用が促進过られ，冬季に於ては楽品の作用虫崌退する のが一般で西る.

それでこの中間の春秋の候に実験を行つて中庸の成績を以てすれば, 夏季に用いた場 合には好成績を得ることになるのである。然し薬品を蜔虫卵に作用させ卵卵器中に保つ た実験は好ましくないので西る。

又肥料を施主時季は春秋の候に多いのである点からしても上記の如き実験が穻当で西 ると考えられるのである.

実験室冈外に於ての実験に際しては，直射日光を避け，主として陽影の場所に置いた のであるが，之は肥料溜の如き野外に西る尿尿の如く日光の直射を受けないのであるか ら，溫度の上昇は野外の蒋尿溜の如く高度ではないので，実用しけ場合には実験成績よ りも好成績を收めることは勿論で西る。

即ち実験成績は極めて厳格な規格の下に得たものであることになるのである。

殺卵剤の効力判定：屎尿中に薬品を混和して殺卵作用灾検するに当つては上述の如 
く薬品在使用して実験的に試験したので西るが蜔虫卵を対称としたので，この蜔虫卯を 收集し, 之在適溫に保ち卵款內に生成方る蜔仔虫の有無によつて, 該蛔虫卵の生死を判 定したのである.

薬品蛋投入混和後 2 日，4日，6 日，8 日，10日目每に該屎尿の約 1 グラム虎探取し， 之を試験管に容れ，水道水を加えて混和し，沈搌させた後に上部の水を葉て，沈澱物に 再度水道水を加元混和する方法で，蜔虫卵度水洗したので两るが，之を 5,6 回繰返元 して上淸が澄明になるまでしたので西る・

然る後に管底の約 $2 \mathrm{cc}$ の沈澱水を残し，之に 10 パーセントのホルマリン水の 2,3

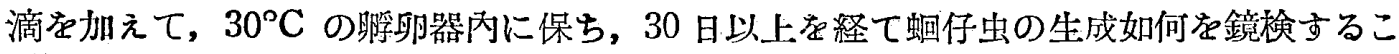
ととしたので西る。

蛔虫卵の検查は 30 個を単位とし，次の如く判定成績を定めたので西る.

30 個の蛔虫卵中 仔虫形成数

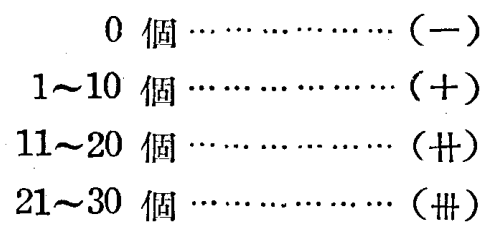

3. 実 験 成 績

前述の考虑のもとに行つた实験に䏳いた薬品は 84 種に及んだので西るが，前述の諸 条件に合格するものは 1,2 種に過ぎないので西る. 即ち極めて制限された条件に合格 するものは極めて少いもので西る。

従来報告されている殺卵作用两りと称せられる薬品も吾々の条件に当てはあれば殆ん ぞ不合格となるので㐫る。

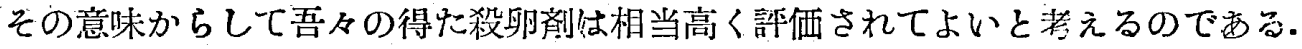

吾々の実験成續の一部として殺卵作用の比較的高度のもの4種について，次に記述す ることとする.（第 1 表参照）

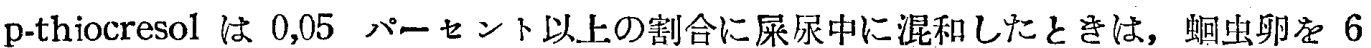
日以內に完全に殺滅古るもので西ることが認められたので西るが，之は薬品の結晶をそ

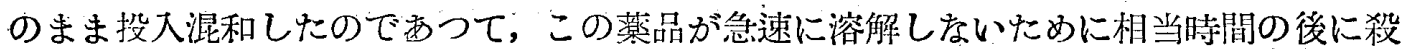
卵作用を発揮するものと考元られるので西るが，之を更に急速に作用せしむべく夫し たので西るが，これについては次回に報告する予定でする。

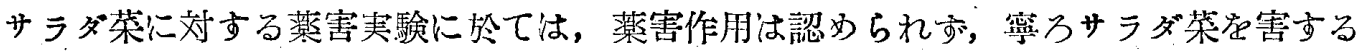

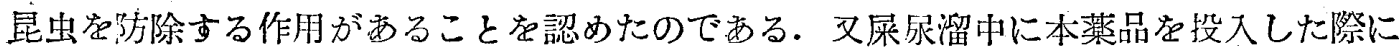

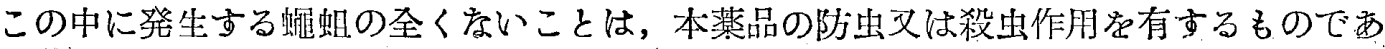
ると考元られるのでする。

それで p-thiocresol は屎尿中の蜔虫卵殺滅戍として実用洒值西るものと刵定しけ。 p.chloro-m-cresol は 0.5 パーセジト以上の割合に康尿中に混和された場合には殺卵 作用を有しているが，この量では実用価做が少いと考元られ，文植物に対する薬害作用 
第 1 . 表

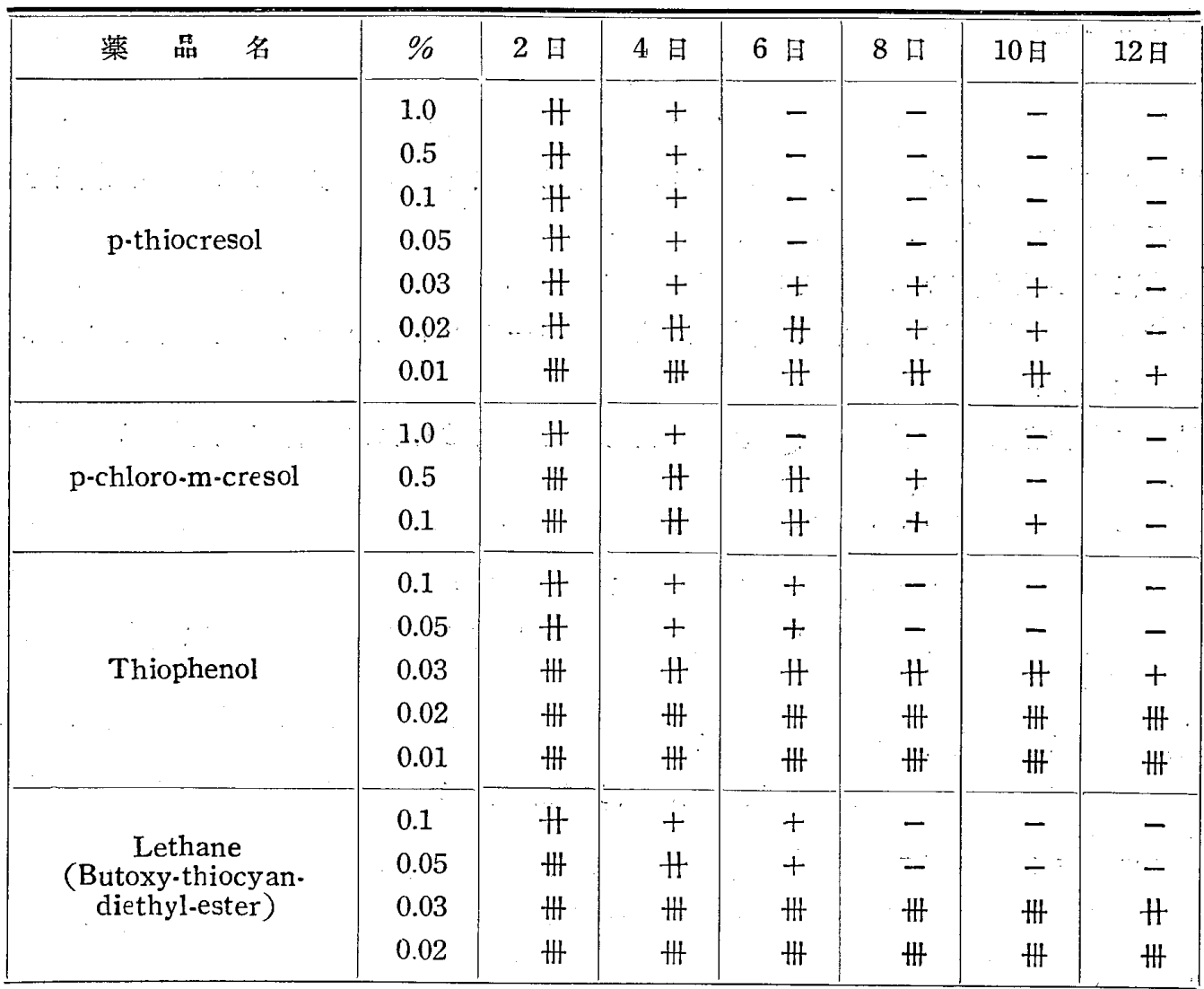

が多少なりとも西ることな認わたので，実用価值は不合格としたのである。

Thiophenol は 0.05 パーセント以上の割合に屎尿中に混和すれば 8日 以內に殺卵作 用を発揮するもので西るが，植物に対する薬害作用が相当に再り，又この薬品は極めて 高度の特異の臭気有して居り, 之存取扱う際には取扱者は強度の作用存受けて頭痛等 を惹起するので，実用価値が全くないものと判定したのである.

Lethane は米国製品で西つて殺出戍として用いられているもので西るが，之も 0.05 パーセント以上の割合に屎尿中に混和した場合に 8 日以內で殺卿作用を発晸するもので 西ること虎認めたので西る。

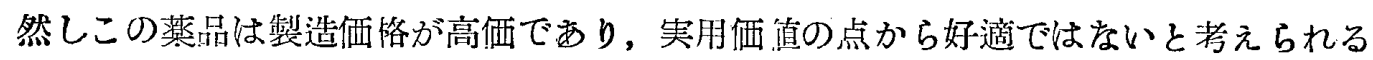
のでする.

其他の薬品中に相当度の殺卵作用を有するものが西るが，何れも p-thiocresol に及 ばないものと判定せられたので西る。

p-thicoresol については野外実験として農家の屎永溜（1石大り）を用いて試験した のであるが，研究空內実験 と全く同様な成績を得たので西る，矢該薬品混大後に屝尿を 麥及び白茶に施肥して検したところ，全く薬害を認めなからたので西る.

又 p-thiocresol と硫安と在混じたものを屎尿溜中に投入し, 該屎尿在肥料として, 
麥に施したところ，麥の成育が㞶照に此較して良好で西つたので西る。

份引続き諸種の薬品について殺卵作用を検索中で西るが，夫等の成績については後日 報告することとする。

\section{5. 結 び}

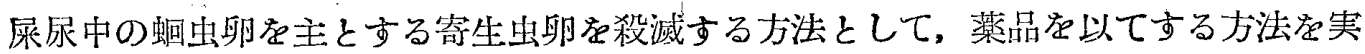
験的に行つたので西る。

実験に当つては種々の条件を定めて，之に合格したものを実朋価值西りとしけ。

条件としては康层に混和する薬品の量は 0.1 パーセント以下とし，殺卵作用を発揮す る時閒は 10 日以內としたので㐫る.

康尿に混和された薬品は，そのまま肥料として使用せられた昜合に農作物に無害なる のでなければならない。

以上に適合した薬品とし、て実用価值西りと認められたものは，p-thiocresol で两つ て, 之は 0.05 パーセントの割合に屎尿中に混和せられて後 6 日以內で全蜔虫卵存殺滅 する作用有しているのであり，該康尿を肥料として使用して，農作物に無害で西るこ と农認めたので西る。

向屎尿中に本薬剂安混和した場合には蠅蛆の如き昆虫類が屎尿溜に発生することを防 止すると共に肥料として農作物に施した祭に該農作物に昆虫類が害学与えること都ぐ ことも認められたので西る。 